\title{
APPENDIX 3: NAMES
}

The spelling of proper names in this translation follows that of the American Standard Version (ASV) of 1901. Proper names provided the translators and copyists with unique difficulties. When a particular letter in a common noun was difficult to read in their Hebrew or Syriac exemplar, they could guess at the unclear letter because they recognized the meaning of the noun. But in the case of proper names that occur rarely in the Bible, translators and copyists had to read the Hebrew/Syriac consonants as best they could. As a result, the Peshițta spells many rare names differently from the Hebrew Bible. This evidence raises questions about the quality of the manuscripts.

Syriac readers of this edition will quickly note that the Syriac spelling and vocalization of many names is not reflected in the English text which, as noted above, follows the ASV. When a name differs significantly from what appears in the MT, I have followed the Syriac text and included a note with the name in the MT (ASV). These names are listed below as replacements. In cases where the Peshitta reflects the exact consonants of the MT, it usually does not reflect the Masoretic vocalization. In these cases the ASV spelling is followed in this translation.

The Syriac translator often writes Hebrew names with matres lectionis. The Hebrew qibbûs can be written with a mater lectionis, such as Vم תִ בְבל in Gen 10:2. In many instances the Peshițta adds a medial • as a mater

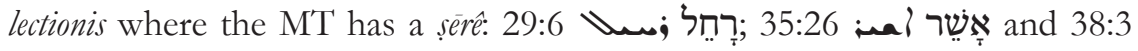

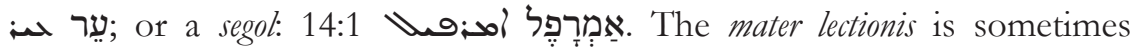
optional as in the case of the names the Leiden Edition has where a medial $Z$ is added. These expected variations in orthography are not listed below. ${ }^{1}$

${ }^{1}$ For a thorough discussion of this feature, see Janet W. Dyk and Percy S. F. van Keulen, Language System, Translation Technique, and Textual Tradition in the Peshitta of Kings (MPIL 19; Leiden / Boston: Brill, 2013), 227-235. In the list below, only the first mention of a proper name is listed. 


\section{Replacements}

In these instances the Peshițta name differs widely from the Hebrew name.

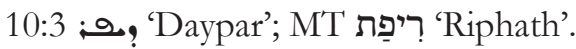

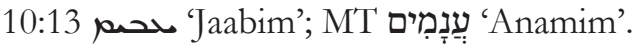

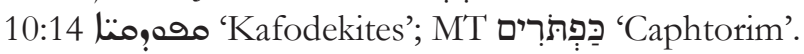

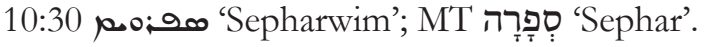

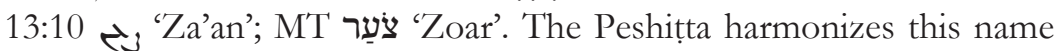

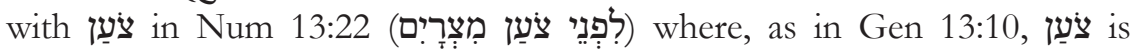
associated with Egypt. See also Pss 78:12,43; Isa 19:11,13.

14:1 'Gelites'; MT ג'וֹיִ 'Goiim'.

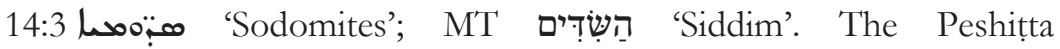
harmonizes this place name with the name Sodom in 14:2 (see also 14:10).

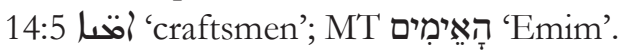

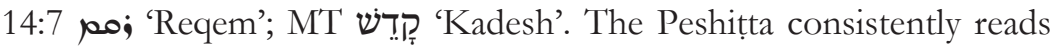

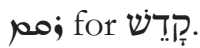

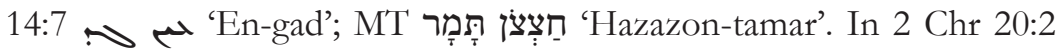
the name Hazazon-tamar is linked to En-gedi.

16:7 שוּר 'Gadar'; MTh'. This is a harmonization with 16:14

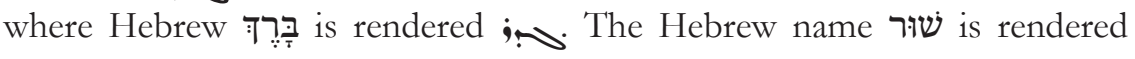
isain in Gen 20:1.

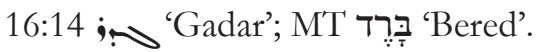

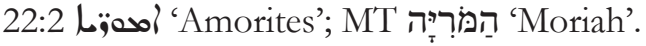

22:23 هما: 'Rebekah'.

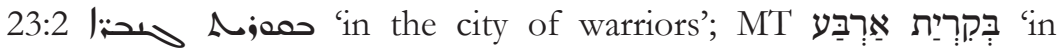
Kiriath-arba'. The Peshițta translation here may be related to Josh 14:15 (Kن معiriath-arba of the warrior men') where the city of Kiriath-arba is said to be the home of a strong man.

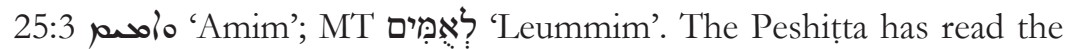
Hebrew ? as if it were the Syriac direct object marker which is normally prefixed to proper names in the accusative.

28:9 מָחָלַת 'Basemath'; MTalath'. The name Mahalath appears only here. In Gen 26:34 Esau married Basemath the daughter of Alon the Hivite. In 28:9 the Peshitta replaces Mahalath with Basemath, harmonizing this hapax legomenon with the more common name Basemath. Similarly, Targum Pseudo Jonathan ensures that its readers understand that Mahalath is just another name for Basemath.

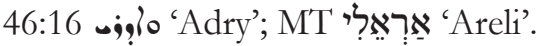




\section{Translations}

On a few occasions the Peshițta translates a name.

14:5 הָרְפָאִים 'Rephaim'. The Rephaim are first mentioned in the list of peoples whose lands will be transferred to Abram. The Peshitta translates this name with 'giants' (see also Gen 15:20).

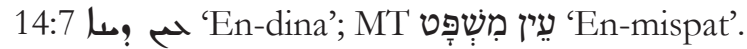

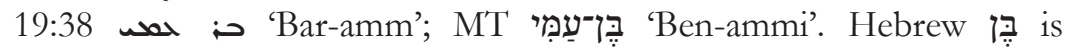
translated into Syriac with حصن حص:

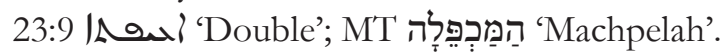

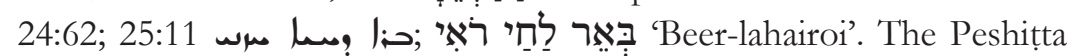
loosely translates the Hebrew place name with 'the Well of the Living One who saw me'.

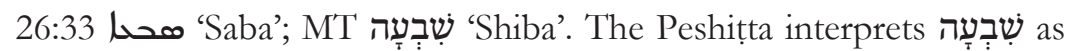
שִׁבְעָה so that the name of the well can be associated with the idea of 'satiation'.

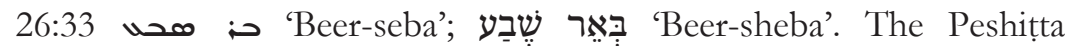
develops a word play based upon the translation

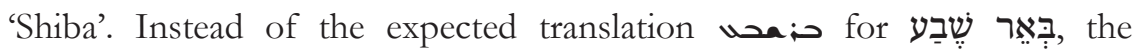
Peshițta reads حم: Breer-seba, meaning, 'The Well of Satiation'.

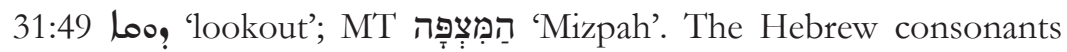
can be interpreted as a place name, Mizpah, or as a noun, 'watchtower, lookout'.

35:8 אַלוֹ בָּכוּת : 'Ollon-bacuth'. The Peshițta, instead of borrowing the Hebrew name, translates the name into Syriac.

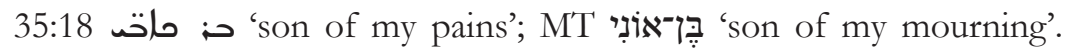
The Peshitta has translated the name of Rachel's son within the context of Rachel's suffering during childbirth.

\section{Initial locations}

\section{Additions}

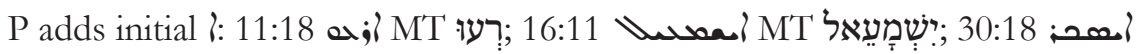

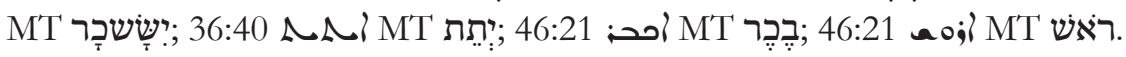

\section{Replacements}

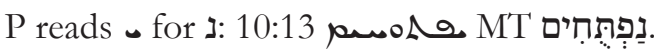

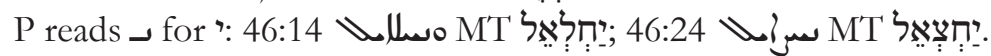

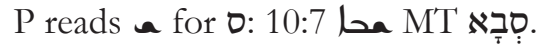

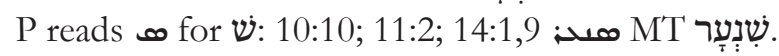




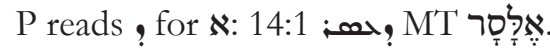

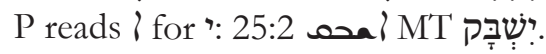

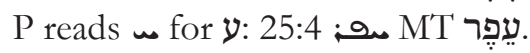

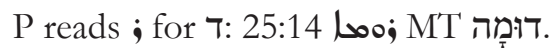

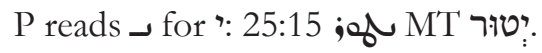

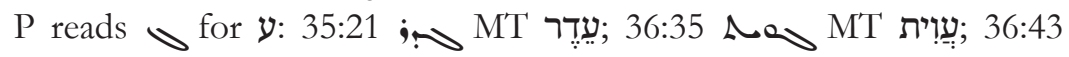
MT עִירָם M.

\section{Transpositions}

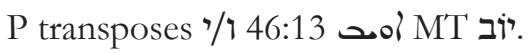

\section{Medial Locations}

\section{Additions}

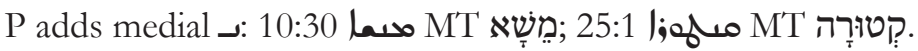

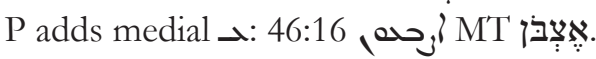

\section{Deletions}

Loss of medial aphel: רִּוּמָה 22:24 MT.

\section{Replacements}

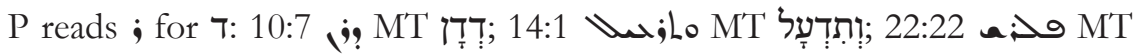

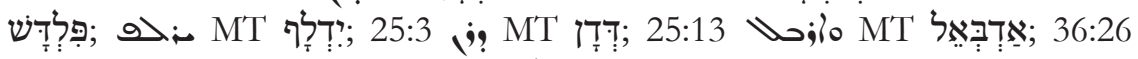

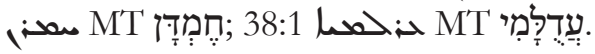

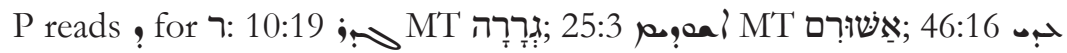
MT עַרִי

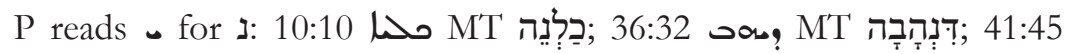

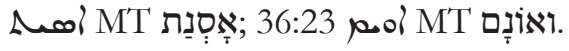

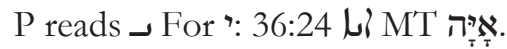

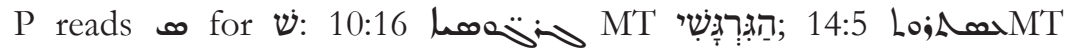
עַשְְׁתרּת

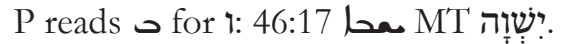

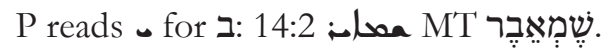

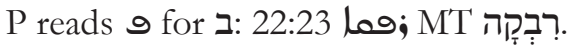

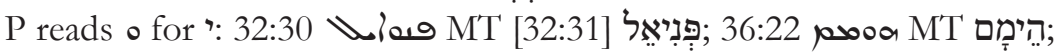

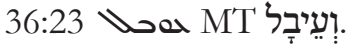

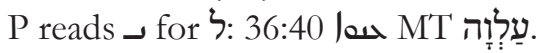

\section{Transpositions}

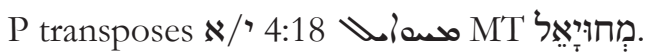

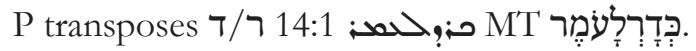




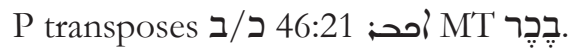

\section{Final locations}

\section{Loss of final}

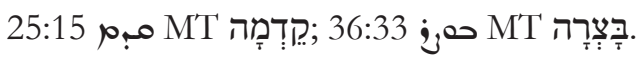

\section{Replacements}

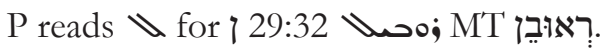

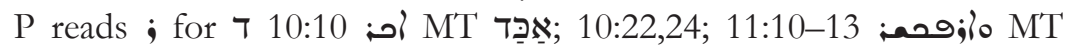

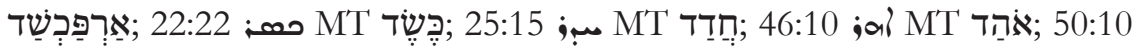
,

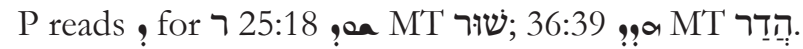

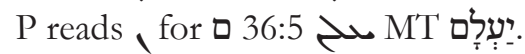

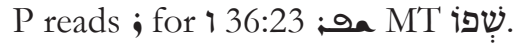

\section{Transpositions}

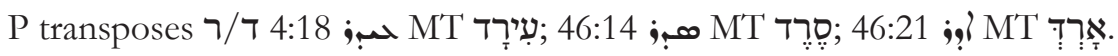

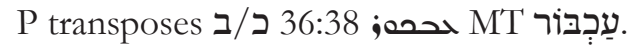

\section{Qere/Ketib}

On occasion the Peshitta reads the qere.

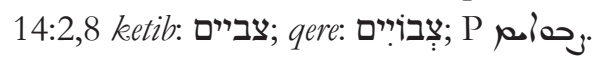

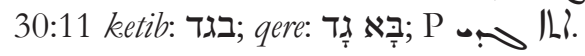

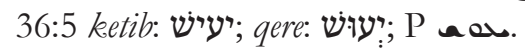


